UDK 630*38:625.7/.8]:582.685.4(560 Bursa)

\title{
ROAD EDGE EFFECT ON BASAL AREA INCREMENT IN LINDEN STANDS
}

Uticaj šumskih puteva na prirast temeljnice rubnih stabala u sastojinama lipe

\author{
Burhan Gencal ${ }^{1}$, İnanç Taş ${ }^{1}$, Abdullah E. Akay ${ }^{1}$
}

\begin{abstract}
Road networks within the forested areas are essential structure to access forests for various purposes such as management, protection, regeneration, harvesting, and recreation etc. However, if roads are not planned properly they may result in serious impacts on forest ecosystems including degradation and fragmentation of habitats. On the other hand, light availability along the road edge increases which reflects the diversity and amount of plant species. In the study, it was aimed to investigate the rod edge effect on tree growing by measuring the basal area increment along road network located within the linden stands. The study area was selected from Karacabey province of Bursa where linden has the largest distribution in Turkey. In the field study stage, four sample trees were selected from 5-meter-wide stripes at the road edge and from control zone which is about 50 meters away from the road edge. Measurements were repeated for 6 sample road sections with 500 meters length along $3 \mathrm{~km}$-long road located in the middle of linden stands. Since the stand characteristics were mostly uniform and did not vary significantly along the sample road, stand structures such as tree ages, stand density, canopy, etc. were not evaluated in this study. During the data collection, the diameter at breast height (DBH) was measured for the sample trees located in the specified zones. Then, statistical analysis was conducted to indicate whether there is a difference in basal area increments between the trees at road edge and the trees located in control zone. According to the results, increasing the distance from the road edge resulted in reduction in the average basal area values. There was a statistically significant difference between basal area values for trees at road edge and the trees located in control zone.
\end{abstract}

Key words: road network, edge effect, basal area, tree growth

\section{INTRODUCTION - Uvod}

Road networks have vital roles for sustainable management of forest resources, however, they may cause negative effects on forest ecosystems when they are not well planned considering ecological factors (EKER and ÇOBAN, 2010). The road edge can influence the integrity and stability of natural habitats in forest

\footnotetext{
${ }^{1}$ Faculty of Forestry, Bursa Technical University, Turkey
} 
ecosystems (GÜLCl et al 2017; KHAMCHA et al 2018). Forest roads include main structures such as road surface, ditches, and cut/fill slope components that provide habitat for associated plants and animals (LUGO and GUCINSKI, 2000). Besides, growth and reproduction of plant species may increase in road edge habitats compared with interior habitat due to variation in temperature, moisture, and light availability (GEHLHAUSEN et al 2000; BACH et al 2005). The width of the road also effects growth of neighbouring trees since the road width affects the amount of light availability along the road edge (GIEFING et al 2003).

DELGADO et al (2007) stated that the edge effect can vary with the distances from the road gap. The microclimate edge effects can extend to the surrounding habitats from a few meters to hundreds of meters from the road (FORMAN et al 2002). NAGHDI et al (2017) conducted a study where edge effect of forest roads on tree growth was investigated considering different distances from the roads and different diameter classes in northern forests of Iran. They reported that the annual diameter and basal area increment were reduced with increasing distance from roads. It was also stated that diameter and basal area increment was increased by increasing the diameter classes. In a similar study conducted by PICCHIO et al (2018), the effects of road existence on changes in stand structure and abundance of species were evaluated. It was reported that tree biodiversity indices at the road edge (i.e. $20 \mathrm{~m}$ from the forest road network) were higher than that of the interior forest.

In this study, the rod edge effect on tree growth was investigated by measuring the basal area of linden trees along a sample road network. The study was implemented in Karacabey province of Bursa where linden has the largest distribution in Turkey. Basal area measurements were obtained from sample trees of two diameter classes (i.e. $25-35 \mathrm{~cm}$ and $35-45 \mathrm{~cm}$ ) from both at the road edge and from control zone which is away from the road edge.

\section{MATERIAL AND METHODS - Materijal i Metode}

\section{Study Area - Područje istraživanja}

The study was implemented in Yeniköy Forest Enterprise Chief in the border of M.Kemalpaşa Forest Enterprise Directorate (FED) located in the city of Bursa (Figure 1). There is one of the largest Linden forests in the region where there are 700 hectares of Caucasian Linden (Tilia rubra) forests and 400 hectares of Silvery Linden (Tilia tomentosa) forests. Field data were collected along the sample road section with 3-km length and 4-meter wide. 


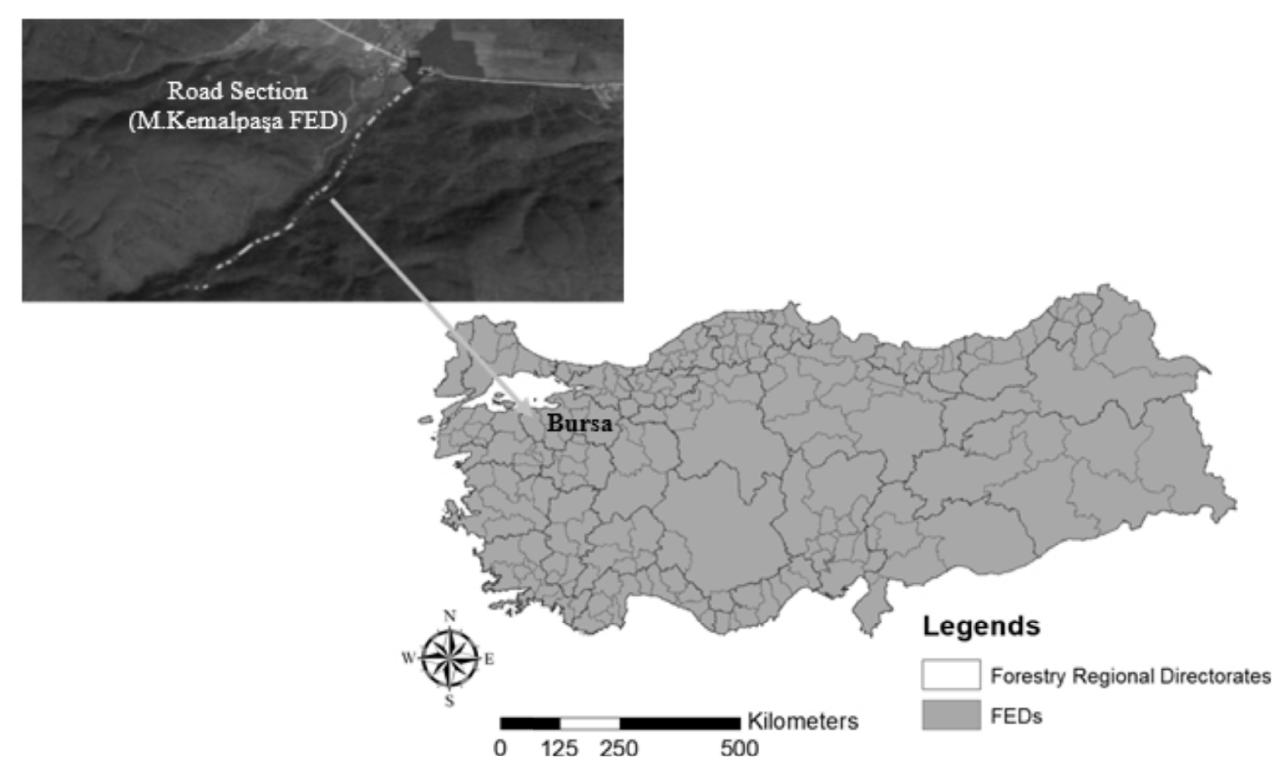

Figure 1. The study area

Slika 1. Područje istraživanja

\section{Methods - Metode}

Field data were collected from sample trees at 5-meter-wide stripes from the road edge zone and from the control zone which is about 50 meters away from the road. During the data collection, the diameters at breast height $(\mathrm{DBH})$ were measured from two sample trees for two diameter classes (small; $25-35 \mathrm{~cm}$ and large; $35-45 \mathrm{~cm}$ ) in both zones. Measurements were made in sample road sections with a 500-meter length along $3 \mathrm{~km}$-long road section (Figure 2). Then, basal area values of sample trees were calculated using following formula (UZOH and RITCHIE, 1996):

$$
B A=\frac{\pi d^{2}}{4}
$$

$B A=$ basal area $\left(\mathrm{cm}^{2}\right)$

$d=$ tree diameter $(\mathrm{cm})$ 


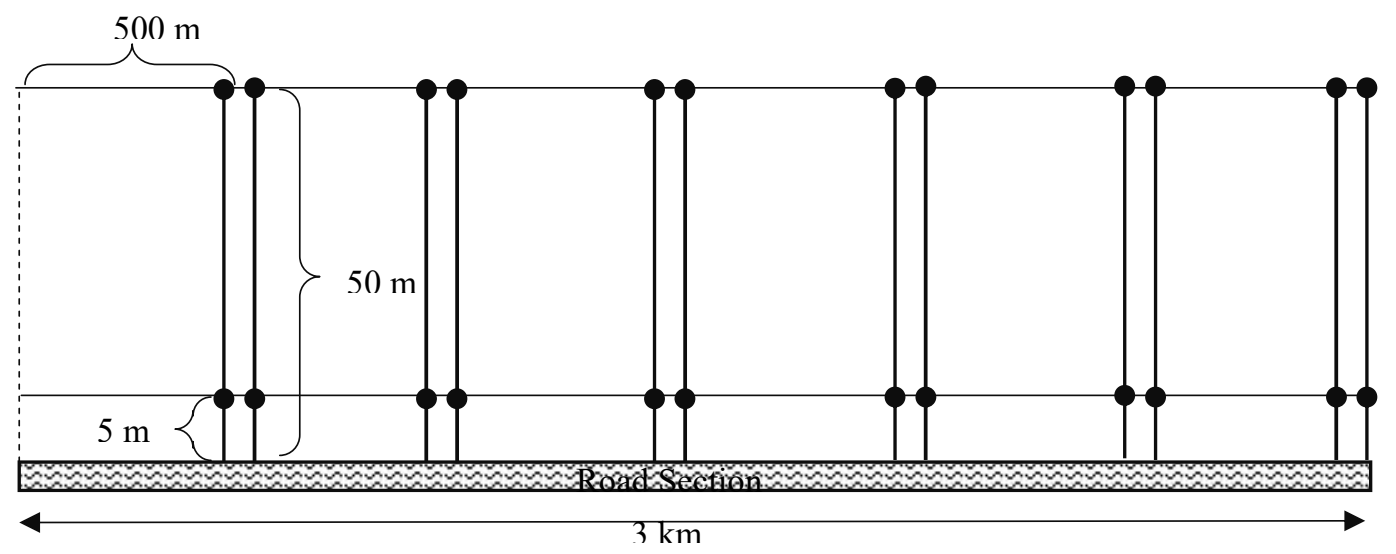

Figure 2. Field data collection pattern along the road section Slika 2. Šema plana površina za prikupljane podataka duž sekcije puta

To assess the significance of observed differences in average basal area on the road edge zone and from the control zone, One-way ANOVA analysis was used. Then, Tukey's test was run to compare the basal area values between two zones for two diameter classes. In statistical analysis, SPSS 16.0 was used and the significance level of $\alpha=0.05$ was applied.

\section{RESULTS and DISCUSSION - Rezultati i Diskusija}

The road edge effect on Linden tree growing by measuring the basal area along road network located within the linden stands was investigated. Table 1 indicates the average basal area of the sample trees with different diameter classes at both zones in the sample road sections. The results showed that the average basal area of sample trees for the both dimeter classes were higher at the road edge zone (Table 2 ). Thus, increasing the distance from the road, the average basal area tends to decrease (STEMPSKI and JABLONSKI, 2014). 


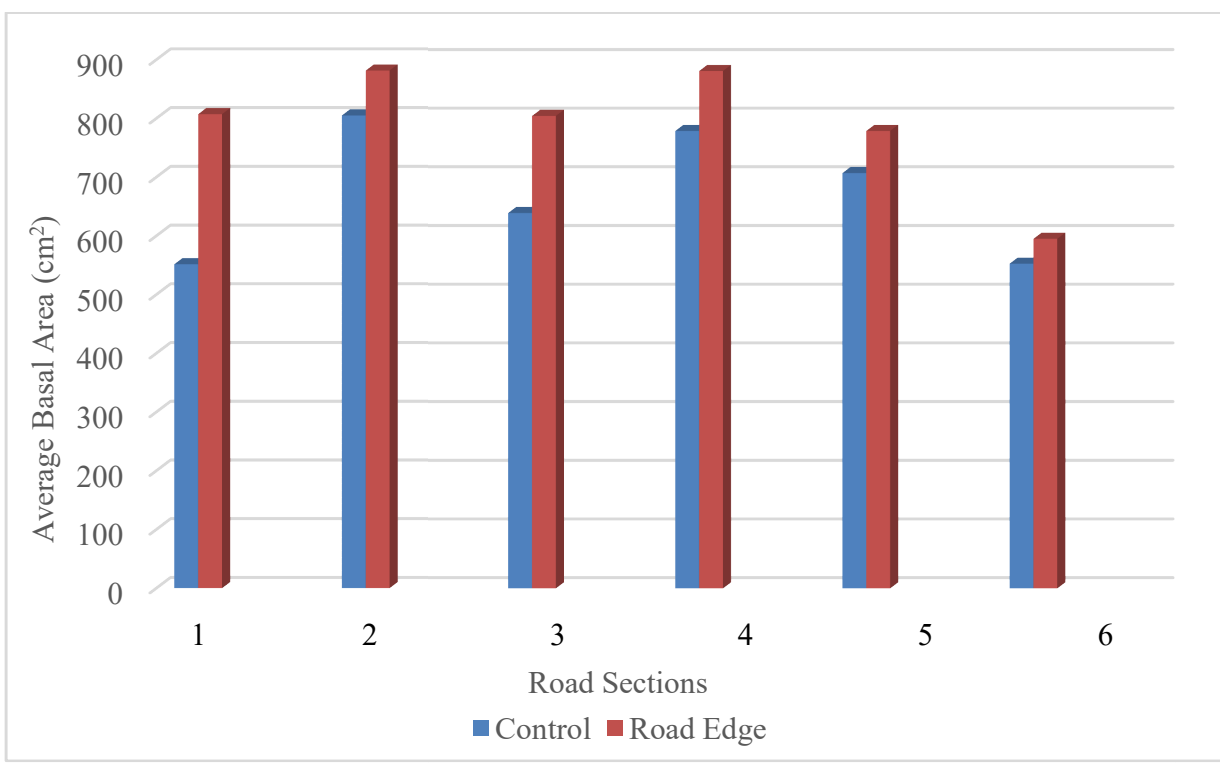

Figure 3. Basal area values in small diameter class for two road distance classes Slika 3. Temeljnica stabala niže debljinske klase za površine na rubu puta i kontrolne površine

In a similar study, NAGHDI et al (2017) indicated that there is a significant difference between the average basal area in different diameter classes. They reported that the highest basal area was in the class with $50 \mathrm{~cm}$ dimeter, while the lowest was measured in the class with $25 \mathrm{~cm}$ diameter. Similarly, the results from this study suggested that average basal area increased as DBH class increased at both zone. At road edge zone, it was found that the average basal area of sample trees was 791.81 $\mathrm{cm}^{2}$ for small DBH class, while it was $1287.29 \mathrm{~cm}^{2}$ for large DBH class. Thus, the average basal area difference was about $494.48 \mathrm{~cm}^{2}$ between two diameter classes at the road edge. The results also indicated for the control zone that the average basal area of sample trees was $672.83 \mathrm{~cm}^{2}$ for small DBH class, while it was $1145.54 \mathrm{~cm}^{2}$ for large DBH class. Thus, the average basal area increased by $472.71 \mathrm{~cm}^{2}$ from small DBH class to large DBH class at the control zone. 


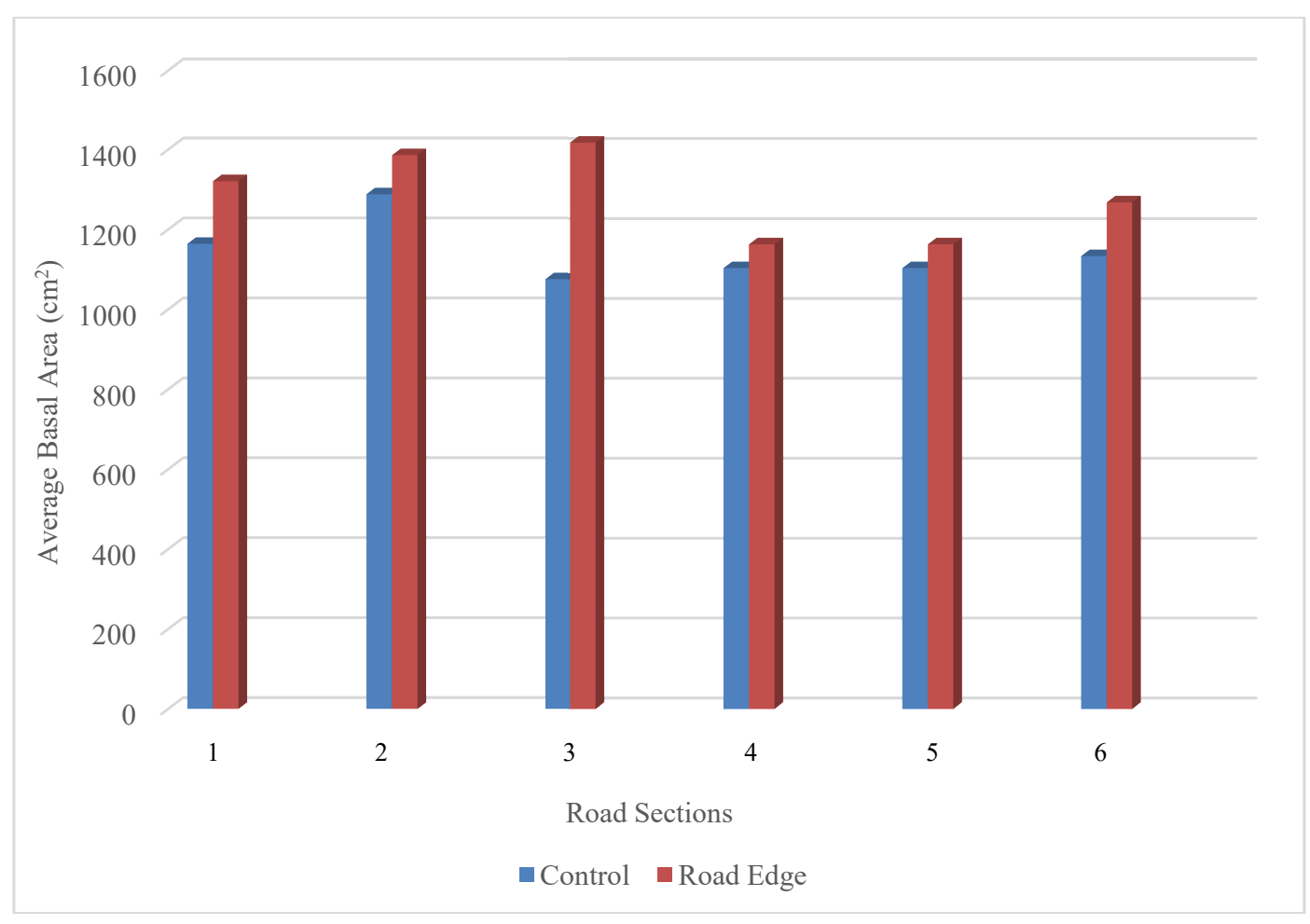

Figure 4. Basal area values in large diameter class for two road distance classes

Slika 4. Temeljnica stabala više debljinske klase za površine na rubu puta i kontrolne površine

Table 1. The average BA of the sample trees with different diameter classes at both zones Tabela 1. Prosječne veličine temeljnice odabranih stabala za dvije debljinske klase

\begin{tabular}{ccccc}
\hline \multirow{2}{*}{$\begin{array}{c}\text { Road } \\
\text { Section }\end{array}$} & \multicolumn{2}{c}{ Small Diameter Class } & \multicolumn{2}{c}{ Large Diameter Class } \\
\cline { 2 - 5 } & $\begin{array}{c}\text { Road Edge Zone } \\
\left(\mathrm{cm}^{2}\right)\end{array}$ & Control Zone $\left(\mathrm{cm}^{2}\right)$ & $\begin{array}{c}\text { Road Edge Zone } \\
\left(\mathrm{cm}^{2}\right)\end{array}$ & Control Zone $\left(\mathrm{cm}^{2}\right)$ \\
\hline 1 & 807.39 & 551.74 & 1321.04 & 1164.35 \\
2 & 881.61 & 805.03 & 1386.23 & 1288.45 \\
3 & 805.03 & 639.71 & 1418.82 & 1076.00 \\
4 & 881.61 & 779.51 & 1164.35 & 1104.66 \\
5 & 779.51 & 707.64 & 1164.35 & 1104.66 \\
6 & 595.72 & 553.31 & 1269.20 & 1134.90 \\
\hline
\end{tabular}


Table 2. Average tree basal area values $\left(\mathrm{cm}^{2}\right)$ for two zones for two diameter classes Tabela 2. Prosječne veličine i statistički pokazatelji varijabiliteta temeljnice stabala $\left(\mathrm{cm}^{2}\right) \mathrm{na}$ rubu puta i na kontrolnoj površini

\begin{tabular}{|c|c|c|c|c|c|c|c|c|c|}
\hline & & \multirow[b]{2}{*}{$\mathrm{N}$} & \multirow[b]{2}{*}{ Mean } & \multirow[b]{2}{*}{$\begin{array}{c}\text { Std. } \\
\text { Deviation }\end{array}$} & \multirow[b]{2}{*}{$\begin{array}{l}\text { Std. } \\
\text { Error }\end{array}$} & \multicolumn{2}{|c|}{$\begin{array}{l}95 \% \text { Confidence } \\
\text { Interval for Mean }\end{array}$} & \multirow[b]{2}{*}{ Min } & \multirow[b]{2}{*}{ Max } \\
\hline & & & & & & $\begin{array}{l}\text { Lower } \\
\text { Bound }\end{array}$ & $\begin{array}{l}\text { Upper } \\
\text { Bound }\end{array}$ & & \\
\hline \multirow{3}{*}{$\begin{array}{l}\text { Road } \\
\text { Edge } \\
(5 \mathrm{~m})\end{array}$} & Small DBH & 12 & 791.81 & 115.973 & 33.479 & 718.13 & 865.50 & 531 & 908 \\
\hline & Large DBH & 12 & 1287.29 & 155.677 & 44.940 & 1188.37 & 1386.20 & 1018 & 1521 \\
\hline & Total & 24 & 1039.55 & 286.471 & 58.476 & 918.58 & 1160.52 & 531 & 1521 \\
\hline \multirow{3}{*}{$\begin{array}{l}\text { Control } \\
(50 \mathrm{~m})\end{array}$} & Small DBH & 12 & 672.83 & 116.240 & 33.556 & 598.97 & 746.68 & 491 & 855 \\
\hline & Large DBH & 12 & 1145.54 & 84.945 & 24.522 & 1091.56 & 1199.51 & 1018 & 1320 \\
\hline & Total & 24 & 909.18 & 261.162 & 53.310 & 798.90 & 1019.46 & 491 & 1320 \\
\hline
\end{tabular}

Table 3. ANOVA analysis of basal area values in different zones

Tabela 3. ANOVA veličine temeljnice stabala na rubu puta i na kontrolnoj površini

\begin{tabular}{llccccc}
\hline & & Sum of & & & \\
& & Squares & df & Mean Square & F & Sig. \\
\hline Road & Between Groups & 1472967.90 & 1 & 1472967.90 & 78.172 & 0.00 \\
Edge & Within Groups & 414538.39 & 22 & 18842.65 & & \\
$(5 \mathrm{~m})$ & Total & 1887506.29 & 23 & & & \\
\hline Control & Between Groups & 1340728.47 & 1 & 1340728.47 & 129.37 & 0.00 \\
$(50 \mathrm{~m})$ & Within Groups & 228002.83 & 22 & 10363.77 & & \\
& Total & 1568731.30 & 23 & & & \\
\hline
\end{tabular}

One-way ANOVA analysis also showed that there was a statistically significant difference between basal area values in different tree diameter classes for both zones $(\mathrm{p}<0.001)$ (Table 3$)$. Figure 3 and 4 indicates the basal area values in two diameter classes for two road distance zones. The results indicated that average basal area increment from road edge zone to control zone was higher for small diameter class $(17.68 \%)$ compared to large diameter class $(12.38 \%)$. The results of a previous investigation also showed that tree growth near the roads had larger DBH values than trees growing inside the stand (STEMPSKI and JABLONSKI, 2014). 


\section{CONCLUSION - Zaključak}

The road edge effect on basal area of trees was investigated by considering the various tree diameter classes and distances from a sample road network located within the Linden forests. Linden trees whose flowers are one of the most valuable non-wood products in Turkey. It was found that increasing the distance from the road edge results in reduction in the average tree diameters as well as basal area values. Thus, the distance from the road plays important role on tree growth due to light availability along the edge habitats. The results indicated that the road edges can provide suitable habitats for Linden trees. In Turkey, Linden flower is one of the most valuable nonwood products mainly used in medical and cosmetic industries because of its active substances such as tannins, oils, and gum. In addition, boiled Linden flowers are consumed as herbal tea to prevent cold and relax nervous system. In order to estimate potential impacts of road edges on other non-wood products further studies should be conducted on growth, survival, and density of different species along road edges.

\section{REFERENCES- Literatura}

BACH, C., KELLY, D., HAZLETT, B. (2005): Forest edges benefit adults, but not seedlings, of the mistletoe Alepis flavida (Loranthaceae). Journal of Ecology, 93(1): 79-86.

DELGADO, J.D., ARROYO, N.L., ARÉVALO, J.R., FERNÁNDEZ-PALACIOS, J.M. (2007): Edge effects of roads on temperature, light, canopy cover, and canopy height in laurel and pine forests (Tenerife, Canary Islands). Landscape and Urban Planning, 81: 328-340.

EKER, M., ÇOBAN, H.O. (2010): Impact of road network on the structure of a multifunctional forest landscape unit in southern Turkey. Journal of Environmental Biology, 31:157-168.

FORMAN, R.T.T., SPERLING, D., BISSONETTE, J.A., CLEVENGER, A.P., CUTSHALL, C.D., DALE, V.H., FAHRIG, L., FRANCE, R., GOLDMAN, C.R., HEANUE, K., JONES, J.A., SWANSON, F.J., TURRENTINE, T., WINTER, T.C. (2003): Road Ecology. Science and Solutions. Island Press, Washington, D.C., USA.

GEHLHAUSEN, S.M., SCHWARTZ, M.W., AUGSPURGER, C.K. (2000): Vegetation and microclimatic edge effects in two mixedmesophytic forest fragments. Plant Ecology 147: 21-35.

GIEFING, D.F., KARASZEWSKI, Z., ZIEMSKI, Z. (2003): The effect of strip roads established during late cleanings on the selected parameters of trees. Sylwan 3:11-18.

GÜLCI, S., AKAY, A.E., OĞUZ, H., GÜLCI, N. (2017): Assessment of the Road Impacts on Coniferous Species within the Road-Effect Zone Using NDVI Analysis Approach. Fresenius Environmental Bulletin. 26(2a):1654-1662. 
KHAMCHA, D., CORLETT, R.T., POWELL, L.A., SAVINI, T., LYNAM, A.J,. GALE, G.A. (2018): Road induced edge effects on a forest bird community in tropical Asia Avian Res (2018):9-20. https://doi.org/10.1186/s40657-018-0112-y.

LUGO, A.E., GUCINSKI, H. (2000): Function, effects, and management of forest roads. Forest Ecol. Manage, 133: 249-262.

NAGHDI, R., BONYAD, A., AMINI, A.M. (2017): Road effect on diameter growth of trees in Caspian forests of Iran, Caspian J. Environ. Sci. 15(1): 47-55.

PICCHIO, R,, TAVANKAR, F., VENANZI, R., LO MONACO, A., NIKOOY, M. (2018): Study of Forest Road Effect on Tree Community and Stand Structure in Three Italian and Iranian Temperate Forests. Croatian Journal of Forest Engineering. 39(1): 57-70.

STEMPSKI, W., JABLONSKI, K. (2014): Differentiation of Tree Diameters at Strip Roads in a Young Pine Tree-Stand. Acta Sci. Pol. Silv. Colendar. Rat. Ind. Lignar. 13(1): 37-46.

UZOH, F.C.C., RITCHIE, M.W. (1996): Crown Area Equations for 13 Species of Trees and Shrubs in Northern California and Southwestern Oregon. Pacific Southwest Research Station Research Paper PSW-RP-227. 14 p.

\section{SAŽETAK}

Mreže puteva u šumskim područjima bitan su strukturni element za pristup šumama za različite svrhe, kao što su upravljanje, zaštita, obnova, sječa i rekreacija itd. Međutim, ako putevi nisu pravilno planirani, mogu dovesti do ozbiljnih štetnih uticaja na šumske ekosisteme, uključujući degradaciju i fragmentaciju staništa. S druge strane, povećana količina svjetlosti duž ruba puta utiče na broj i raznolikost biljnih vrsta. Cilj ovog rada je da se ispita efekat ruba puta na rast stabala lipe na osnovu prirasta temeljnice stabala koja rastu pored puteva u sastojinama lipe. Područje istraživanja je odabrano u provinciji Karacabey u Bursi, gdje je lipa najviše zastupljena u Turskoj. Na terenu su izabrana po 4 stabla na 6 pruga duž puta i na kontrolnim prugama udaljenim oko $50 \mathrm{~m}$ od ruba puta. Širina pruga je $5 \mathrm{~m}$, a dužina $500 \mathrm{~m}$ te je na taj način obuhvaćeno područje dužine $3 \mathrm{~km}$ duž puta koji se nalazi u sredini sastojina lipe. Sastojine lipe obuhvaćene uzorkom uglavnom su homogene strukture te uticaj strukturnih karakteristika sastojine, kao što su starost stabala, gustina sastojine, sklop itd., nije razmatran $\mathrm{u}$ ovoj studiji. Prilikom prikupljanja podataka odabranim stablima su izmjereni prsni prečnici (DBH). Statističkom analizom je provjereno postojanje razlika u veličini temeljnice između stabala na rubu puta i stabala na kontrolnim površinama. Prema utvrđenim rezultatima, sa povećanjem udaljenosti od ruba puta smanjuje se prosječna veličina temeljnice, a razlike između sredina veličina temeljnice stabala na rubu puta i stabala na kontrolnim površinama su statistički značajne.

Corresponding author: Burhan Gencal: Bursa Technical University, Faculty of Forestry, 16310 Bursa, Turkey; e-mail address: burhan.gencal@btu.edu.tr 